\title{
Suriyeli Mültecilerin Esnaflaşmasını Anlamada Bourdieucu Yaklaşımın Olanakları
}

\author{
Olgu Karan' 1
}

Öz

Bu çalışmada mültecilerin esnaflaşmasında karşılaştıkları sorunları anlamak için kullanılan kuramsal çerçevelerin, bütüncül bir bakış açısı sağlayamadığı, karşılaştıkları zorluklardaki dinamikleri ve baş etme stratejilerini anlamakta yetersiz kaldığı iddia edilip, bu bağlamda Bourdieu sosyolojisinin kavramlarının sosyal araştırmacılara ne gibi olanaklar sağladığı araştırılmaktadır. Mülteci esnaflaşmasında karşılaşılan dinamiklerin aydınlatılmasında daha bütüncül, ilişkisel bir bakış açısı Bourdieucu yaklaşımın alan kuramıyla sağlanabilir mi sorusunu tartışmaya açmak çalışmanın temel amacını oluşturmaktadır. Bu bağlamda Türkiye'de yaşayan mültecilerin esnaflaşmasının dinamiklerini anlamak için Bourdieu sosyolojisinin kavramları işlemselleştirilerek varolan göçmen/mülteci girişimcilik yazınındaki boşlukların Bourdieu’nun çok katmanlı ilişkisel kavramları ile kapatılması hedeflemektedir. Dolayısıyla sosyal araştırmacılara mülteci esnafların yaşadıkları sorunları anlamada kullanabilecekleri kuramsal bir alet çantası sunmayı amaçlamaktadır. Göçmen girişimcilik literatürü üç ana başlık etrafinda değerlendirilecektir. Bunlar, fail merkezli teoriler kültürelcilik ve ulusüstücülük, yapısalcı teori ve sosyal gömülme teorileri olarak gruplandırılacaktır. Farklı analitik araçların ve teorilerin odaklandığı temalar değerlendirilip teorilerdeki boşluklar vurgulanacaktır. Bourdieucu yaklaşımın ilişkisel kavramları tartışılacaktır. Son olarak, bahsi geçen kavramlar işlemselleştirilerek mülteci esnafların yaşadıkları sorunları anlamada kullanılabilecek kavramsal çerçeve sunulacaktır.

\section{Anahtar Kelimeler}

Suriyeli mülteci esnaflaşması • Aracı göçmen azınlıklar • Geçici göçmen zihniyeti • Etnik kümelenme ekonomileri • Kültürelcilik • Ulusüstücülük • Yapısalcı teori • Sosyal gömülme teorileri • Pierre Bourdieu

Opportunities for Understanding Syrian Refugees' Entrepreneurship in Turkey Using the Bourdieusian Approach

\section{Abstract}

This study shows that existing theoretical approaches in understanding migrant small-business ownership do not provide a composite, multi-layered framework. The dynamics of hardship faced by Syrian refugees and Syrian survival strategies are asserted to be unable to be fully understood through existing theoretical approaches. The existing literature on refugee-owned small businesses is discussed under three groupings: agency-oriented theories, structuralism, and the mixed approaches of embeddedness. This paper adopts a Bourdieusian approach to exploring the opportunities provided by Bourdieusian sociology in understanding the multi-layered dynamics of Syrian entrepreneurship. The main research questions of the paper are as

1 Olgu Karan (Dr. Öğr. Üyesi), Başkent Üniversitesi, Fen-Edebiyat Fakültesi, Sosyoloji Bölümü, Ankara.

E-posta: olgukaran@gmail.com ORCID: 0000-0002-1581-1987

Atıf: Karan, O. (2019). Suriyeli mültecilerin esnaflaşmasını anlamada Bourdieucu yaklaşımın olanakları. İstanbul Üniversitesi Sosyoloji Dergisi, 39(2), 249-276. https://doi.org/10.26650/SJ.2019.39.2.0010 
follows: What are the possible opportunities in Bourdieu's concepts for shedding light on Syrian small-business ownership? Does Bourdieusian field theory provide a composite, relational approach in understanding Syrian refugee small-business ownership? In so doing, the multi-layered and relational concepts of Bourdieusian sociology are operationalized in order to fill in the gaps within the existing literature on migrant/refugee entrepreneurship. This paper provides researchers with a toolkit for working on migrant/refugee smallbusiness ownership and contains five sections. The first section sets the aim and methodology of the study. The second section discusses the analytical models for understanding migrant entrepreneurship. The third section elaborates on the theoretical approaches that shed light on migrant entrepreneurship. These last two sections critically engage with these models and theoretical approaches by showing the gaps within them. The fourth section sets out the Bourdieusian approach and operationalizes his concepts into the research area of Syrian small-business ownership in Turkey. The paper concludes with key research findings and implications for researchers and practitioners.

\section{Keywords}

Syrian refugee entrepreneurship - Middleman minorities - Sojourner mentality • Enclave economies • Culturalism •Transnationalism • Structuralism • Social embeddedness • Pierre Bourdieu

\section{Extended Summary}

The Syrian internal war that erupted in 2011 led millions of Syrians to leave their countries looking for refuge in Turkey. According to the figures provided by the Republic of Turkey's Ministry of Interior Directorate General of Migration Management, the number of Syrians under temporary protection with registered biometric data was 3,674,588 as of October 10, 2019 (Mülteci Derneği, 2019). As Turkey hosts more than 3 million Syrians, the refugee integration policies regarding access to health, education, labor market, and citizenship are under intense public debate. Syrian entrepreneurs residing in specifically near border regions and big metropolitan cities like İstanbul are also known to have set up small shops in various sectors. According to the Union of Chambers and Commodity Exchanges of Turkey, 173 corporations and 8,038 limited companies operating with Syrian financial capital are found between January, 2013 and April, 2019 (TOBB Kurulan-Kapanan Şirket İstatistikleri, 2019). Accordingly, migrant entrepreneurship has been asserted to not only be able to foster migrant's self-reliance and integration into the host society, but also to be able to ease the social and cultural adaptation processes of migrants into their new environment (Özservet, 2017, p. 3). In this respect, analyzing the dynamics and the difficulties within the field of migrant entrepreneurship is essential.

This study shows that the existing theoretical approaches in understanding migrant small-business ownership do not provide a composite, multi-layered framework. It asserts that the dynamics of hardship faced by Syrian refugees and Syrian survival strategies cannot be fully understood by existing theoretical approaches. The existing literature on refugee-owned small businesses is discussed under three groupings: agency-oriented theories, structuralism, and mixed approaches of embeddedness. However, the paper adopts a Bourdieusian approach to explore the opportunities 
provided by Bourdieusian sociology in understanding the multi-layered dynamics of Syrian entrepreneurship. The main research questions of the paper are as follows: What are the possible opportunities for Bourdieu's concepts to shed light on Syrian small-business ownership? Does Bourdieusian field theory provide a composite, relational approach to understanding Syrian refugee small-business ownership? In so doing, the multi-layered and relational concepts of Bourdieusian sociology have been operationalized in order to fill the gaps within the existing literature on migrant/refugee entrepreneurship. By using the full theoretical model of Pierre Bourdieu's multi-layered relational concepts, the study aims to develop a more nuanced understanding of the dynamics in migrant entrepreneurship. The paper provides researchers with a toolkit for working on migrant/refugee small-business ownership.

The paper contains five sections. The first section sets the aim and methodology of the study. The second section discusses the analytical models in understanding migrant entrepreneurship. The third section elaborates on the theoretical approaches that shed light on migrant entrepreneurship. These last two sections critically engage with these models and theoretical approaches by showing the gaps within them. The fourth section sets out the Bourdieusian approach and operationalizes his concepts into the research area of Syrian small-business ownership in Turkey. The paper concludes with key research findings and implications for researchers and practitioners. The methodological approach performs a critical evaluation of the theoretical approaches and analytical models to understand the dynamics within migrant entrepreneurship. Accordingly, a small number of academic studies on Syrian entrepreneurship in Turkey are discussed in relation to the theoretical approaches and analytical models. In addition to the critical elaboration of secondary resources regarding the literature on Syrian entrepreneurship in Turkey, I have utilized the field work observations I made during the research project titled A New Perspective on the Processes of Adaptation and Integration of Urban Refugees: A Social Innovation Experiment Aimed at Building Inclusive Cities, which was funded by the Scientific and Technological Research Council of Turkey's (TÜBİTAK) Priority Area R\&D Funding Program No. 1003 (117K826) where I worked as a researcher. Next, a multi-level research framework that incorporates the micro, mid, and macro dynamics within Syrian entrepreneurship is presented using Bourdieusian concepts. Finally, the Bourdieusian concepts are operationalized into Syrian small-business ownership.

Rather than borrowing piecemeal from Bourdieu's work, Bourdieu's full theoretical account opens up fresh and innovative possibilities for theoretical and empirical research. The research shows how Bourdieu's concepts, field, habitus, and forms of capital are constitutively bound up within each other. First, one of the advantages of Bourdieu's theory in the context of small business ownership lies in its dynamic approach that enables discussion on how changes in the political economy have affected 
migrant labor markets and immigrants' interests and employability, particularly ethnic entrepreneurship. A Bourdieusian approach calls for an assessment of deeper political structures and the power relations that shape the current configuration of social and economic life.

The concept of habitus offers a powerful means for linking the micro and macro processes in ethnic entrepreneurship. The habitus also links past fields to present fields and enables researchers to conduct comparative studies, as habitus takes into account the entrepreneur's own sense of the structures, meanings, and definitions that people bring to their situation in the confrontation and negotiation between themselves and the structures.

Adjusting to the field of entrepreneurship requires investment and the transformation of forms of capital that are needed in small business ownership. The formation and activation of social, cultural, and economic capital, rather than pre-existing, exists solely in relation to the field of entrepreneurship. A Bourdieusian approach enables researchers to focus on the formation and reproduction of concrete social network ties in a specific field. As Bourdieu and Wacquant (1992, p. 101) put it, "Capital does not exist and function except in relation to a field."

Moreover, the findings from the study suggest that not all Syrian shopkeepers possess these capitals equally. The ability to overcome difficulties in small business ownership is dependent on the volume and quality of social capital. Inequalities in the distribution of forms of capital in a particular moment in time could lead to different entrepreneurial strategies within the members of the Syrian community.

This study shows that existing theoretical approaches for understanding migrant small-business ownership do not provide a composite, multi-layered framework. It asserts that the dynamics of hardship faced by Syrian entrepreneurs cannot be fully understood through existing theoretical approaches.

The Bourdieusian framework has a greater potential for explaining the dynamics within Syrian entrepreneurship and provides researcher better analytical tools for understanding the dynamics of Syrian small-business ownership. 


\section{Suriyeli Mültecilerin Esnaflaşmasını Anlamada Bourdieucu Yaklaşımın Olanakları}

2011 yılında Suriye'de ortaya çıkan iç savaş sonucunda milyonlarca Suriyeli Türkiye'ye göç etmek zorunda kalmıştır. İçişleri Bakanlı̆̆g Göç İdaresi Genel Müdürlüğü 10 Ekim 2019 tarihi itibarıyla Türkiye'deki biyometrik verileriyle kayıt altına alınan geçici koruma altındaki Suriyeli sayısının 3 milyon 674 bin 588 kişi olduğunu açıklanmıştır (Mülteci Derneği, 2019). Suriyeli mültecilerin sayısının üç buçuk milyonu aşmasıyla beraber Türkiye, Suriyelilerin eğitim, sağlık hakkında erişimi ve işgücü piyasasında istihdamı konusunda entegrasyon politikaları oluşturmaya çalışmaktadır. Suriyeli girişimcilerin özellikle sınır bölgelerinde ve İstanbul gibi büyük metropollerde çoğu küçük ölçekli olmak üzere çeşitli sektörlerde işletme açtıkları bilinmektedir. TOBB istatistiklerine göre 2013 Ocak-2019 Nisan arasında Suriyeli sermayesiyle faaliyet gösteren 173 anonim şirket ve 8038 limited şirket kurulmuştur (Türkiye Odalar ve Borsalar Birliği, 2019) Dolayısıyla göçmen girişimciliği göçmenlerin geldikleri ülkede kendi ayakları üzerinde durabilmesini, sosyal hayatın içinde yer alabilmelerini sağladığı gibi kültürel ve sosyal adaptasyon süreçlerini beraberinde getirebileceği ve psikolojik durumlarını olumlu etkileyebileceği iddia edilmektedir (Özservet, 2017). Dolayısıyla, göçmenlerin girişimcilik dinamiklerini, girişimcilik süreçlerinde karşılaştıkları zorlukları anlayabilmek, analiz edebilmek önemlidir.

$\mathrm{Bu}$ çalışmada mülteci esnafların karşılaştıkları sorunları anlamak için literatürde kullanılan kavramsal ve kuramsal çerçevelerin birleşik, bütüncül bir bakış açısı sağlayamadıkları iddia edilmektedir. Bu bağlamda Bourdieu sosyolojisinin kavramları sosyal araştırmacılara ne gibi olanaklar sağlayabilir? Mülteci esnafların karşılaştıkları çok boyutlu sorunların bir incelemesine dair Bourdieu sosyolojisinin olacakları nedir? Göçmen esnafların karşılaştıkları dinamiklerin aydınlatılmasında daha bütüncül ve ilişkisel bir bakış açısı, Bourdieu sosyolojisinin alan kuramıyla sağlanabilir mi sorusu tartışmak çalışmanın temel amacını oluşturmaktadır. Bu bağlamda, Türkiye'de yaşayan göçmenlerin esnaflaşma dinamiklerini anlamak için Bourdieu sosyolojisinin kavramlarını işlemselleştirilerek varolan göçmen girişimcilik yazınındaki boşluklar Bourdieu'nun çok katmanlı ilişkisel kavramları ile kapatmayı, sosyal araştırmacılara esnaf göçmenlerin yaşadıkları sorunları anlamada kullanabilecekleri kavramsal pencere sunmayı amaçlamaktadır.

Çalışma kapsamında, ilk olarak göçmen esnaflaşmasında yaşanan dinamikleri ve sorunları anlamada kullanılan kuramsal çerçeveler değerlendirilecektir. Türkiye' deki Suriyelilerin esnaflaşmasını anlamada yapılan çalışmaların işlemselleştirdiği kuramsal yaklaşımlar ve araştırmaların çerçeveleri bu bağlamda değerlendirilecektir. İkincil kaynakların kullanımına ek olarak bu çalışmanın yazarının araştırmacı olarak görev aldığı TÜBİTAK'ın 1003 - Öncelikli Alanlar Ar-Ge Projeleri Destekleme Programı 
kapsamında Hatay'daki Suriyelilerin adaptasyon süreçlerine dair yapılan saha çalışmasından elde edilen gözlemlerden yararlanılmıştır.

Yazı beş bölümden oluşmaktadır. Giriş bölümünde çalışmanın amacı ve metodolojisi açıklanacaktır. İkinci bölümde göçmen esnaflaşmasını anlamada kullanılan analitik araçlar tartış1lacaktır. Üçüncü bölümde göçmen esnaflaşmasına 1şık tutan teorik yaklaşımlara odaklanılacaktır. Bu iki bölümde farklı analitik araçların ve teorilerin odaklandığı temalar değerlendirilip bu model ve teorilerdeki boşluklar vurgulanacaktır. Dördüncü bölümde Bourdieu'nun kavramları tartışıldıktan sonra Suriyeli küçük işletme sahiplerinin yaşadıkları dinamikleri anlamak için Bourdieu'nun kavramları alana uyarlanacaktır. Bu bölümde Bourdieu sosyolojisinin kavramları işlemselleştirilerek esnaf göçmenlerin yaşadıkları sorunları anlamada kullanılabilecek kuramsal bakış açısı sunmak amaçlamaktadır. Sonuç bölümünde Bourdieu sosyolojisinin göçmen girişimciliği çalışan araştırmacılara sağladığı avantajlar belirtilecektir.

\section{Göçmen Esnaflaşmasını Anlamada Kullanılan Analitik Araçlar}

Göçmen esnaflaşmasını anlamada kullanılan analitik modelleri ve kuramları üç grupta toplayabiliriz. Bunlar, fail merkezli teoriler (Altinay ve Altinay, 2006; Basch ve ark., 1994; Basu ve Altınay, 2002; McEvoy ve Hafeez, 2007; Light, 1972; Srinivasan, 1995; Werbner, 1984, 1990), yapisalc1 teoriler (Aldrich ve ark., 1981; Waldinger ve ark., 1990; Volary, 2007) ve sosyal gömülme teorileri (Kloosterman, Van der Leun ve Rath, 1999; Kloosterman ve Rath, 2001, 2003; Rath, 2002; Pang ve Rath, 2006) olarak gruplandırılabilir.

Analitik araçlar, tipolojik modeller olarak bir olgunun tipolojiye yakınlığını ya da uzaklığını ölçmek için kullanılırlar. Aşağıdaki bölümlerde üç analitik model tartışılacaktır. İlk analitik model aracı göçmen azınlıklardır.

\section{Aracı Göçmen Azınlıklar (Middleman Migrants-Minorities)}

Göçmen esnaflaşmasını anlamada Bonacich'in (1973) “aracı azınlıklar” modelinin uzun bir geçmişi vardır. Aracı azınlıklar, bir malın üreticiden nihai tüketiciye ulaşmasına kadar olan aşamalarında alım ve satım işleri ile uğraşan azınlık veya göçmen kişidir. Aracı yaklaşım, geniş nüfus yığınlarına çeşitli servisler tedarik eden belirli etnik gruba odaklanır (McEvoy ve Hafeez, 2007, s. 5). Aracı azınlıklar kavramı etnik işletme sahiplerinin kitleler ve elitler arasında işgal ettikleri pozisyonun analiz edilmesini sağlar.

Bonacich ve Modell'a (1980) göre aracı azınlıklar, yönetici sınıflar ile halk arasında tampon işlevi görür. Kavram, sömürgeleştirilen insanların elit tabakasının sömürenler ve sömürülenler arasında tampon rolü oynamasına işaret etmesi sebebiyle sömürge 
ekonomilerinden devşirilmiştir. Kavram, göçmen girişimciliği yazınında azınlık göçmenler ile egemen etnik grup arasında tampon rolü oynayan küçük burjuva - azınlık elitler - azınlıkları tanımlamak için kullanıma sokulmuştur. Min'in (2008, s. 69) belirttiği üzere "aracı azınlıklar ticari faaliyetlerde yoğunlaşmakta ve genellikle egemen grubun ürettiği ürünleri azınlık tüketicilere satmaktadır”. Azınlıklar asıl üretici olmamakla birlikte, elitlerle halk arasında çalışırlar. Klasik yoruma göre, kapitalist sınıf ile işçi sınıfı arasındaki orta sınıf olarak görülürler. Şehirleşmiş toplumlarda aracı azınlıklar, elitlerin ürünlerini geçim kaynaklarının kıt, polis korumasının sınırlı, gelir seviyesinin düşük, belediyeler tarafından sağlanan yerel hizmetlerin zayıf olduğu yoksul mahallelerde satan kişilerdir. Büyük zincir işletmeler düşük gelir seviyesi, yağmalama ve kundaklama gibi suçların yüksek oranı sebebiyle bu mahallelere yatırım yapmayı tercih etmezler. Bu koşullarda aracı azınlıklar, satılan ürünlere ihtiyaç duyan yoksulların kolay hedefi haline gelir (Gold, 2010). Bonacich'e (1987, s. 461) göre aracı azınlıklar büyük zalimlerin işini yapan paravan yüzüdür. Sömürge ekonomilerinde aracılar, beyaz adamın şehirdeki yüzüdür.

Aracı azınlıklar, etnik işletme sahiplerinin toplumsal yapıda oynadıkları rolü anlamak için analitik bir araçtır. Fakat bu yaklaşım etnik azınlıkların niçin aracı olduklarını, neden ve nasıl esnaflaştıklarını açıklamaz. Söz konusu grubun özelliklerine ve fonksiyonuna odaklanır (bk. Bonaich ve Modell, 1980).

\section{Etnik Kümelenme Ekonomileri (Enclave Economies)}

Göçmenlerin esnaflaşmasını anlamak için kullanılan bir başka model ise Portes ve çalışma arkadaşlarının geliştirdiği “etnik kümelenme ekonomileri”dir (Portes ve Bach, 1985; Wilson ve Portes, 1980). Portes'e (1981) göre, etnik kümelenme ekonomilerinin iki özelliği bulunmaktadır: Bir, göçmenlerin yerleşim bölgelerinde yoğunlaşmaktadırlar. İki, yerleşim bölgelerinde oturanlar büyük çoğunluğu ortak etnik kökenden oluşmaktadır (Drori ve Lerner, 2002). Yerleşime göre yoğunlaşma etnik kümelenme ekonomilerinin tanımlayıc özelliğidir (Portes ve Manning, 1986, s. 330):

Etnik kümelenme ekonomisi tamamen oluştuğunda yeni gelen göçmenin bölge sınırları içinde yaşaması, ihtiyaçlarını ve karşılamaları mümkündür. İş, eğitim olanaklarına ve çeşitli hizmetlere erişim etnik ekonominin oluştuğu bölgenin sınırları dışına çıkmadan mümkündür. Bu kurumsal eksiksizlik yeni gelen göçmenlerin ekonomik adaptasyonuna olanak sağlar.

Etnik kümelenme ekonomilerindeki esnaflar neredeyse bütünüyle yerelde bulunan etnik ortak kökenden gelen göçmenlerin kaynaklarına bağımlıdırlar. Bu kaynaklar, enformasyon, sermaye, sosyal ağlar ve işçilerdir (Drori ve Lerner, 2002; Light ve Bonacich, 1988; Light ve Gold, 2000; Waldinger ve ark., 1990). 
Aracı azınlıklar modeliyle karşılaştırıldığında, etnik kümelenme ekonomileri etnik ortak kökenden gelen insanların yoğunlaştığı yerleşim bölgelerine odaklanır. Aracı azınlıklar farklı bölgeler ve gruplar arasında hareket ederken, etnik kümelenme ekonomilerindeki göçmenler bir bölgenin sınırları içinde hayatlarını sürdürürler. Etnik kümelenme ekonomileri modelini savunanlara göre, etnik azınlıklar etnik yemek, kitap, müzik, giysi gibi kültürel ürünlere ihtiyaç duyar. Bu ihtiyaçlar etnik işletme sahiplerince karşılanabileceği düşüncesiyle bu ekonomilerin temel dayanağını oluşturduğu varsayılır. Bu ürünlerin bilgisine sahip etnik işletme sahipleri ürünleri azınlık gruba temin edebilir. Bu yaklaşımı savunanlar etnik kümelenme ekonomilerinde göçmenlerin ana-akım iş piyasasında çalışan göçmenlerden daha iyi maddi kazanç sağladığını iddia ederler (Portes ve Bach, 1985; Portes ve Manning, 1986). Etnik topluluğun yoğunlaştı̆̆ bölgeler çok çeşitli göçmen işletmeleri destekler ve etnik grubun farklı sektörlerdeki varlı̆̆ının devamını sağlarlar.

Etnik kümelenme ekonomileri zamanla ortadan kalkabilir. Örneğin, bölgenin demografik yapısının değişmesi, kümelenmenin dağılmasına bir sebeptir. Yeni gelen göçmenler genellikle etnik kümelenme bölgelerine yerleşir ve bu bölgelerde yeni işyerleri açarlar. Böylece bölge insanlar ve işletmeler bakımından değişir. Birçok durumda, yeni gelen grup göçmen, eski göçmen grubu yerinden eder (Terzano, 2010).

Light ve Gold'a (2010) göre etnik kümelenme ekonomileri yaklaşımına yöneltilebilecek itiraz, modelin bölgesel kümelenmeye bağımlı oluşu sebebiyle sosyal ağların ve ulus ötesi bağlantıların göçmen işyeri sahiplerine kaynak oluşturmadaki önemini yok saymasıdır. Örneğin, göçmenlere kültürel ürün tedarik eden göçmen işletme sahipleri geldikleri ülkelerdeki insanlarla kurdukları düzenli ilişkilere dayanarak göçmenlerin kültürel ürün elde etme ve tüketme arzularını sömürürler. Dolayısıyla, göçmenlerin yoğunlaştı̆̆ bölgelerdeki yerel kaynakların sömürüsünün dışında göçmenler yerelin dışındaki sosyal ağlarında kaynak oluştururlar. Etnik kümelenme ekonomilerinin ayrılmaz bir parçası bu nedenle ulus üstü sosyal sermayedir ve sosyal ağlar yerel etnik kümelenme ekonomilerinin dışına taşar. Örneğin, göçmenlerin damak zevkine hitap etmeyi hedefleyen bir göçmen esnaf adayı, söz konusu göçmen grubunun mutfağını iyi bilen bir aşçıya ihtiyaç duyar. Göç edilen ülkenin yerel yemeklerini yapacak aşçıları yetiştirecek okullar ve dolayısıyla aşçllar bulunmuyorsa, lokanta açmak isteyen göçmen işletme sahibi adayı geldiği ülkeden aşçı getirmek zorunda kalacaktır. Bu tür örnekler etnik kümelenme ekonomilerin ne ölçüde kümelenme ekonomileri olduğunu tartışmaya açar. Dahası, perakende sektörü göç edilen ülkeden düzenli gelen ithal ürünlere ihtiyaç duyar.

\section{Geçici Göçmen Zihniyeti (Sourning Mentality)}

Göçmenlerin esnaflaşmasını anlamak için kullanılan üçüncü model geçici göçmen zihniyetidir. Geçici göçmen zihniyeti, göçmenlerin ağır, zor koşullarda 
uzun saatler çalışmalarının sebebi olarak çokça kullanılmıştır. Geçici göçmenlerin bir özelliği, göçmenlerin uzun yıllar yabancı bir ülkede kalmalarına rağmen asimile olmamalarıdır. Psikolojik olarak geçici göçmen kendisini göç edilen ülkede kalıcı olarak görmez ve kalıcı olmaya yönelik yatırım yapmaz. Geçici göçmen yurt dışında yaşamasına rağmen ana vatanıyla olan bağını asla koparmaz (Siu, 1952). Geçici göçmenler bir bakıma ekonomik göçmenlerdir. Geçici göçmen zihniyeti literatürüne göre, göçmenler gittikleri ülkede bir süreliğine kötü yaşam ve çalışma koşullarına gögüs germeyi göze alırlar. Bunu ana vatanlarına döndüklerinde daha iyi yaşam koşullarına sahip olacaklarını düşündükleri için yaparlar. Bu sebeple uzun çalışma saatlerine katlanırlar. Ana vatanlarına işçi dövizi gönderip fazla tüketmezler (Bonacich, 1973).

Geçici göçmenleri yerleşik göçmenler ve ev sahibi toplum ile karşılaştıran çalışmalara baktığımızda, yerlilerin ve yerleşik göçmenlerin tutumluluk davranışı sergilemediği, geçici göçmenlerin ana vatanlarına döndüklerinde rahat bir yaşam sağlamak amacıyla uzun saatler çalıştıkları, geçici göçmenlerin kısa sürede ana vatanlarında kullanmak üzere sermaye biriktirmeyi arzuladıkları ve dolayısıyla göç edilen ülkedeki gayretli çalışmanın ödülünü ana vatanlarına erteledikleri belirtilir (Pecoud, 2004, s. 20).

Ancak Waldinger'in (1989) belirttiği üzere, yerleşik göçmenlerin sahip oldukları küçük işletmeler aşırı rekabet, düşük gelir, yüksek işletme kapanma oranları, işletme sahipleri ve çalışanları için uzun çalışma saatleri ile karakterize olurlar. Ayrıca, fiziksel ve psikolojik sağlık sorunları uzun çalışma saatlerinin bir sonucudur. Bu sebeplerden dolayı geçici ve yerleşik göçmenlerin uzun çalışması, tutumlu olmaları, birikimlerini ana vatana gönderip tüketim için az para harcamaları ortak özellikleridir.

Waldinger'in (1989) gözlemi göçmenlerin iş hayatını anlamak için geçici göçmen ruhu modeline farklı değişkenleri öne sürdüğü için önemlidir. Örneğin, şiddetli rekabet ve düşük gelir, iflaslara engel olmak için işletme sahiplerinin çalışan işçilerin işine son vermelerine veya uzun çalışma saatlerine neden olmaktadır. Dolayısıyla, göç edilen ülkede sıkıntılara göğüs germeye hazır olma eğilimleri kalış süresi ya da ana vatana dönüş planı ile ilgili olmanın ötesinde, içine gömülü oldukları bağlam ile ilgilidir. Geçici göçmen ruhu göçmenlerin içine yerleştikleri yapısal faktörlere odaklanmayıp ruhsal özelliklerine odaklanır.

\section{Göçmen Esnaflaşmasını Anlamada Kullanılan Teoriler}

$\mathrm{Bu}$ bölümde göçmenlerin esnaflaşma dinamiklerini, sebeplerini anlama ve açıklamakta kullanılan teorik modeller tartışılacaktır. Bu kuramlar üç ana başlık altında toplanmaktadırlar: fail merkezli kuramlar, yapısalcı kuram ve sosyal gömülme kuramlarıdır. 


\section{Kültürelci yaklaşımlar}

Fail merkezli teoriler, göçmen esnafların sahip olduğu değerlerin başarı ya da başarısızlıklarına olan etkisine odaklanır. Kültür ve fail odaklı bu çalışmalar, kültürün ve göçmen grubunun karakteristik özelliklerinin girişimciliğe etkisine odaklanır ve kültürel ve demografik farklılıkların, girişimcilerin performansında farklılaşmaya yol açtığını savunur. Esnafların kişisel özelliklerine odaklanan bu çalışmalara bir örnek olarak Özkul ve Dengiz'in (2018) "Suriyeli Göçmenlerin Girişimci Olmalarını Etkileyen Faktörler: Hatay İli Örneği” başlıklı makalesi verilebilir. 400 Suriyeli mülteci ile yapılan anket çalışmasına dayanan bulgular göçmenlerin girişimci olmalarını etkileyen faktörleri incelemektedir. Araştırmada bağımlı değişken olarak Suriyeli göçmenlerin girişimci olması ele alınırken, bağımsız değişkenler ise sırasıyla cinsiyet, yaş, medeni durum, eğitim, yaşamının çoğunluğunu geçirdiği yer, mesleki tecrübe, iş kurma tecrübesi, aylık gelir gibi Suriyelilerin karakteristik özelliklerine odaklanan demografik verilerin etkisine odaklanılmıştır. Çalışma kapsamında Suriyelilerin girişimci olmasını etkileyen dışsal faktörlere ve bu faktörlerin algılanışına yer verilmemiştir.

Benzer bir çalışmada Kayalar ve Yıldız (2017), girişimci göçmenlerin mobilize edebileceği kaynaklara odaklanırlar. Yazarlar beşeri, kültürel, sosyal ve finansal sermayenin aktive edilerek farklı ülkelerde yapılan çalışmalarında girişimci göçmenlerin başvurdukları kaynakları incelemektedirler. Kaynakların mobilize edildiği bağlamın özellikleri tartışmanın dışında bırakılmıştır.

$\mathrm{Bu}$ araştırmaların varsayımlarına göre, bazı göçmen grupları kültürel olarak girişimciliğe daha yatkındır ve daha donanımlıdır. Kültürel pratiklerin değişmez, sabit olduğu varsayılır ve değişen koşullara uyum sağladıkları göz ardı edilir. Göçmenlerin kendi işinin patronu olma isteği, toplumsal saygı görme ve bağımsız olma arzusu, daha çok para kazanma isteği göçmenleri esnaflaşmaya çeken faktörler olarak kişisel özelliklerine yani faile odaklanır.

Kültürelci yaklaşıma göre göçmenlerin anayurtlarından getirdikleri kültürel özellikler kültürel sermaye olarak görülür. Göçmen girişimci kendisine ait bir işyerini göçmen topluluğunun desteğini alarak sağlar (Cassarino, 1997, s. 3). Göçmenlerin göçtükleri ülkelere aktardıkları kültürel sermayenin ekonomik sermaye elde edilmesini kolaylaştırdığı varsayılmaktadır.

Kültürel açıklamalara farklı perspektiflerden eleştiriler yöneltilmiştir. Bu eleştirilerde öne çıkan vurgu göçmen girişimciliğinin sadece göçmenlerin kişisel özelliklerine ve sahip oldukları özelliklere odaklanarak anlaşılamayacağıdır (Aldrich ve Waldinger, 1990). Kültür modelini eleştirenler, kültürün araştırma alanındaki kullanımı her göçmen grubunu diğerlerinden farklılaştıran ortak değerlerin, normların, geleneklerin olduğunu varsayar (Vermeersch, 2011). Bu görüşe göre, bütün göçmen grupları homojendir ve 
"bilinçleri kolektif bir şekilde programlanmıştır" (Hofstede, 1991). Tutumluluk, sık1 aile bağlarına sahip olma, sıkı soydaş bağları, güven ve fedekarlık gibi özellikler göçmenlerin iş yaşamında rekabet etme güçlerini arttırdığı varsayılır (Altınay, 2008; Altınay ve Altınay, 2006; Basu ve Altınay, 2002; Basu 1998; McEvoy ve Hafeez, 2007; Srinivasan, 1995; Werbner, 1984, 1990). Göçmen işyeri sahiplerinin başarılı olmaları, göçmenlerin doğuştan sahip oldukları nitelikler tarafından belirlenir.

Bir başka ifadeyle, göçmenler işletme kültürüne sahip olanlar ve olmayanlar olarak gruplara ayrılır. Werbner (1984, s. 169) İngiltere'de işyeri sahibi olan Pakistanlılarla yaptığı çalışmada, örneğin "fedakârlık, özveri, sıkı çalışmaya ve tasarrufa önem verme (özetle Protestan ahlakı) Pakistanlı ruhunu karakterize ettiğini”" belirtmektedir. Benzer şekilde, Altınay (2008, s.33), İngiltere'de Türk küçük işletme sahiplerinin göçmen yerleşim bölgelerinin dışına taştığını, bunu da işletme sahiplerinin İslam'la şekillenen geleneksel Türk kültüründen ayrılarak başardıklarını belirtmektedir. Başka bir ifadeyle İslami değerlerin modern kapitalizmle uyumsuz olduğunu varsaymaktadır. Kültürel açıklamalara getirilen eleştiriler bu açıklamaların göçmenler hakkında basmakalıp düşüncelere neden olduğunu (Collins, 2000; Pecoud, 2004), hatta kültürel özelliklerin göçmenlerin doğasından kaynaklandığ varsayılıyorsa, bu teoriler ırkçı açıklamalarla benzerlik göstermektedir (Westwood ve Bhachu, 1988, s. 26). Göçmen olmayan işyeri sahiplerinin birey olarak güçlü girişimci ruhu taşıdıkları varsayılırken, geldikleri ülkelerden getirdikleri kolektif kültürel nitelikler, göçmenlerin ötekiliği esnafların başarılarını belirleyen faktör olarak ölçülür. Böylece, göç edilen ülkelerdeki farklı kültürler ve göçmen grubunun içindeki heterojenlik göz ardı edilir. Kültürelci teorilere göre, göçmenler, azınlıklar ve çoğunluğu oluşturan grup arasındaki eşitsizlik göçmenlerin ötekiliğinin sonucudur dolayısıyla egemen norma olan uzaklıklarını ya da yakınlıklarını ölçmenin bir aracı olarak inşa edilirler. Bir göçmen grubunun ticaretteki başarısı ya da başarısızlığ 1 , uyumsuz ya da uyumlu kültürel özelliklerinin sonucudur. Böylece, göçmen esnaflaşmasına dair kültürelci açıklamalar kapitalist Batı toplumlarıyla diğer toplumlar arasında epistemolojik ve ontolojik fark inşa etmektedirler. Batı dış1 toplumlar "ötekilikle" damgalanmaktadır.

\section{Ulusüstücülük}

Diğer bir fail merkezli kuram ulusüstücülüktür. Basch ve arkadaşlarına (1994, s. 6) göre ulusüstücülük göçmenleri ana vatanlarıyla yerleştikleri ülkeleri çok yönlü sosyal, ekonomik ve politik ilişkiler sayesinde birbirine bağlayarak ulusal sınırları aşan ulusötesi sosyal alanların yaratılmasıdır.

Benzer şekilde Portes (2001, s. 186), uluslararası, çok uluslu terimleri ulusların, diğer ulusal menşeili kurumların ve tek bir ulus devletin sınırlarını aşan kurumların yürüttüğü etkinliklere işaret ederken, ulusötesi aktiviteler gruplar veya bireysel ağların 
organizasyonuyla, kurumsal olmayan aktörler tarafindan başlatılır ve sürdürülür. Kendileri tarafından yürütülen bu aktiviteler devlet kontrolünün ve düzenlemelerinin dışında gayrı resmidir.

Ulusötesi sosyal ağlar kavramı sosyal etkileşim sonucunda gelişen firsatları işaret eder (Portes, 1995). Bu sosyal ilişkieri aktifleştirme ve böylece kaynak mobilizasyonu sosyal sermaye olarak görülür (Bourdieu, 1986). Fail odaklı bu görüş, dünya çapındaki birbirine bağll1ığı derinleştiren, genişleten ve hızlandıran (Held ve ark., 1999; Landolt, 2001) "zaman ve mesafeyi sıkılaştıran” teknolojilerin (Harvey, 1989) önemine vurgu yapar. Ulusötesi girişimciler modern aracı göçmenler olarak adlandırılırlar (Terjesen ve Elam, 2009, s. 1096). En azından iki ülkenin kültürünü bilmek elzemdir. Bu açıdan ulusötesi girişimciler benzersiz perspektifleri ve kaynaklarıyla birden fazla kurumsal ortama girip çıkabilir ve uluslararası ticaret yapabilirler.

Uluslararası göç yazınına en başarılı katkılardan birisini ağ teorisi yapmakla birlikte bu teori göçlerin sebeplerini açıklamaz Ong (1997, s. 1). Kültürelci açıklamalara benzer bir şekilde ulusötesiciliğin sosyal sermayeye ve etnik ağlara olan vurgusu göçmenlerin girişimcilik faaliyetlerindeki niteliksel ve niceliksel farklılıklarının açıklanmasında kullanılır (Engelen, 2001, s. 203). Dolayısıyla, kurumsal boyuta önem verilmeyip göçmen işletme sahiplerinin izole bir biçimde iş gördükleri varsayılır.

Yukarıda tartışılan teorilere ve yaklaşımlara yöneltilen eleştiriler 1şığında bazı eklektik çalışmalar karma gömülmüşlük teorisini ve sermaye türleri yaklaşımı araştırma gündemlerine almıştır (örn, Ram ve ark. 2008; Vershinina ve ark., 2009). Bourdieu'nün kavramlarını kısmen kullanan bu çalışmalar, onun habitus ve alan kavramlarına odaklanmaktan uzak kalmışlardır. İlerleyen bölümlerde Bourdieu sosyolojisinin göçmen esnaflaşmasını anlamadaki rolüne odaklanılacaktır.

\section{Yapısalcı Açıklamalar}

Kültürelci teoriye bir alternatif olan yapısalcı teori, göçmenlerin değişen kültürel, sosyal, ekonomik yapıların bağlamında hareket ettiklerini belirtir. Politik ekonomide meydana gelen değişiklikleri görmezden gelen sanki bir vakumda yaşadıklarını var sayan kültürelci teoriden farklı olarak yapısalcı teori, bireylerin ve grupların tarihsel olarak değişen politik, ekonomik bağlamda hareket ettiklerini vurgular (Pecoud, 2007; Volery, 2007). Yapısalcılara göre göçmen işletmeleri göçmenlerin geldikleri ülkelerden getirdikleri kültürel özelliklerin katkısıyla oluşan izole girişimlerin sonucu olarak ortaya çıkmaz. Bu sebeple, yapısalcılık göçmenlerin karşılaştıkları fırsatların yapısını araştıır. Göçmenlerin dışındaki etkenlerin esnaflaşmaya olan etkisine odaklanır. Göçmenlerin karşılaştıkları yapısal olanaklar ve engeller yapısalcıların araştırmalarının odağında yer alır. 
Kültürelci yaklaşımlardan farklı olarak yapısalcı araştırmaların merkezinde ekonominin yapısı, hükümet politikaları, ırkçılık, etnik ayrımcılık, şiddet ve taciz göçmen esnaflaşmasının belirleyici etkenlerindendir. Bu açıdan iş yeri açma kararını belirleyen çekici (kültürel) faktörler yerine itici (yapısal) faktörlere odaklanır. Odağında göçmenleri esnaflaşmaya iten dişsal etkenler vardır. Yapısalcı bakış açısına göre, hukuki, kurumsal ortam, iş piyasası politikaları, potansiyel piyasanın varlığı göçmen esnafların karşılaştığ1 fırsatların ve engellerin yapısını belirleyen çok önemli etkenlerdir (Rath, 2000).

Çeşitli sektörlerde göçmenlerin iş yeri açması, göçmen işletmelerinin sundukları ürünlere ve servislere talebin olmasına bağladır (Aldrich \& Waldinger, 1990). Bir sektörün meta olmaktan çıkarılma ölçüsü tarihsel koşullara bağlı olarak şekillenip göçmen esnafların beklentilerini şekillendirir. Esping-Andersen'a (1990; 1999) göre, sanayi sonrası topluma geçiş deneyimleyen farklı ulusal kurumsal bağlamlarda yapısal dönüşüm farklı istihdam yollarına neden olmaktadır. Esping-Andersen'dan yola çıkarak, farklı kurumsal yapılar, düzenleyici çerçeveler farklı esnaflaşma yollarıyla sonuçlandığı söylenebilir. Örneğin, kurumsal yapının piyasa, aile ve kamuya ait sınırı belirlediğini iddia eden (Kloosterman ve Rath, 2003) bu sınırı şöyle ifade eder:

Kamu sektörü düşük gelir getiren aktiviteleri üstlendiğinde veya aileye dair hizmetlerin ölçeği göreceli olarak büyükse küçük işletmelere ait faaliyet alanın kapsamı sinırlı olur. Tam tersi durumda ise piyasa aileye ve belediyelere dair bütün servisleri karşılar (Örn, çocuk bakımı, ev temizliği, parkların bakımı gibi).

Hükümetin bu tür servisleri temin etmesi, bu sektörlerde işletmelerin gelişmesine olanak tanımaz (Esping-Andersen, 1990). Dolayısıyla, göçmenlerin ulusal bağlamın düzenleyici çerçevelerine gömülü olması belli bir sektörde esnaf faaliyetin mümkün olup olmamasını belirler. Benzer şekilde çeşitli sektörlerde ücretli işçi olarak çalışan ya da 1rkçılık veya ayrımcılık sebebiyle iş bulamayan göçmenler için küçük işletmelere yönelmek bir kaçış olarak ortaya çıkmaktadır.

\section{Karşılıklı Etkileşim Kuramı (Interaction Theory)}

Kültürelci ve yapısalcı yaklaşımlardan farklı olarak karşılıklı etkileşim teorisi göçmenlerin esnaflaşmasını belirleyen etkenlerin sadece göçmenlerin kişisel özelliklerine odaklanarak ya da yapısalcılar gibi faili yok sayarak anlaşılamayacağını vurgular (Aldrich ve ark., 1990). Karşılıklı etkileşim teorisine göre, yapısalcı ve kültürel analiz göçmen esnaflaşmasının sadece bir yönüne odaklanmaktadır. Bu sebeple Waldinger ve çalışma arkadaşları daha kapsayıcı bir teori ortaya koyarak firsatların yapısını ve fail odaklı görüşleri bir araya getirmişlerdir. Göçmen esnaflaşması böylece göçmen grubun özellikleriyle firsatların yapısı arasındaki etkileşimin ürünü olarak görülmeye başlandı (Collins, 2003, s. 16). Karşılıklı etkileşim teorisi, göçmen esnaflaşmasını göçmenlerin firsatlara erişimine, grup özelliklerine ve değişen tarihsel koşullara gömülü olarak ortaya 
çıkan stratejilere bağlar. Fırsatların yapısı piyasa koşullarıyla (özellikle etnik ve etnik olmayan tüketici piyasalarına erişim) ve mülk sahibi olmaya erişim ile ilişkilidir. Etkileşimci kuram fail ile piyasanın yapısı arasındaki ilişkiye odaklanırken çeşitli bölgelerde farklılaşan failin etnik kaynaklarına ve firsatların yapısına odaklanır.

Fail ve yapıyı bir araya getirmeye çalş̧an etkileşimci kurama yöneltilen eleştiri, kurumsal yapının ve göçmenlerin esnaflaşmasını destekleyici ya da köstekleyici hükümet politikalarının şekillendirdiği düzenleyici bağlama odaklanmadıkları yönündedir. Yani, etkileşimci teori yeni esnaf adaylarının piyasada faaliyet göstermesini bloke eden düzenlemeleri ve kuralları hesaba katmaz (Kloosteran ve Rath, 2001, s.2).

\section{Karma Gömülmüşlük Kuramı (Mixed Embeddedness)}

Yakın zamanda etkileşimci teoriye kıta Avrupasından eleştiriler yöneltilmiştir (Kloosterman, Van der Leun ve Rath, 1999; Kloosterman ve Rath, 2001, 2003; Rath, 2002; Pang ve Rath, 2006). Bu eleştirilerin ortak noktası, etkileşimci teorinin esnaflaşma arzına odaklanması iken, esnaflaşmanın farklı bağlamlarda nasıl yönetildiği ve farklılaştırıldığı göz önüne almamasıdır (Pang ve Rath, 2006). Örneğin, ABD'de hemen hemen herkesin özel işletme açması mümkünken, Almanya'da ve hatta Avusturya'da bireyler özel lisanslara başvurmak zorundadır. Hatta, lokantalarda, barlarda çiçek satmak için bile belirli bir kurumun onayını almak gerekmektedir (Rath, 2007, s. 5).

Bazı yazarlar (Kloosterman, Van Der Leun ve Rath 1999; Kloosterman ve Rath, 2001, 2003; Rath, 2002) daha sofistike karma gömülmüşlük teorisini ortaya atarak düzenleyici yapıların ve piyasa dinamiklerinin önemini vurgulamışlardır. Karma gömülmüşlük yaklaşımının avantajı etnik sosyal ağlar ile ekonomik ve politik yapılar arasında karşılıklı etkileşime odaklanmasıdır. Rath'ın (2002, s. 13) belirttiği üzere, karma gömülmüşlük yaklaşımının önemi, ilişkilerinin ve ticari faaliyetlerinin ekonomik ve politik kurumsal yapılara gömülmüş olmasından ileri gelir.

Etkileşimci model, etnik işletmelerin politik kurumsal yapılarını araştırma kapsamına sokmaz ve piyasa güçlerinin yarattığı ekonomik firsatların ve engellerin yapısına odaklanır (Ram ve Jones, 2008, s. 63). Etkileşimci model devleti gözden kaçırarak ülkeler özelinde etnik işletme performanslarındaki farklılığı açıklama gücünden mahrum kalır. Karma gömülmüşlük teorisi ise kurumsal çerçeve, piyasa yapısının şekli, etnik girişimcilik arzı gibi faktörleri bir araya getiren bir araştırma güzergâhı sunar.

Fakat karma gömülmüşlük teorisi makro yapısal etkenleri gözden kaçırır. Etnik işletme sahiplerinin gömülmüşlüğü ulusal çerçevelerle sınırlıdır. Bu sınırlılık da küresel politik ekonomide meydana gelen ekonomik yapılardaki değişikliklere yetersiz ilgi gösterilmesine neden olur. Küreselleşme ve göçmenler için değişen firsatların yapısı arasında ilişki kurulmadığı gibi özellikle göçmen girişimciliğinin yeni yüzlerini anlamada yetersiz kalır. 


\title{
Bourdieu'nun İlişkisel Kuramı
}

Fail ve yapı ikiliğini aşan ve bir araya getiren, çok katmanlı ve ilişkisel Bourdieucu teorinin örgüt ve işletme çalışmalarına uyarlanması, akademik yazında 2005 yılında Özbilgin ve Tatlı tarafından yapılmıştır. Bourdieu'nun çok katmanlı ve ilişkisel yaklaşımına dair girişimcilik literatüründe kayda değer çalışmalar ise Karatas-Ozkan ve Chell (2015), Karatas-Ozkan (2011) ve özellikle etnik girişimcilik literatüründe İnal (2007a; 2007b) tarafından yapılmıştır.

\begin{abstract}
Alan
Bourdieu'ya göre alan, ilişkisel olarak yapılandırılmış pozisyon konumlarının birbiriyle rekabet eden bireylerle, bireyler ve kurumlar arasındaki somut ilişkileridir (Bourdieu,1987). Alan kavramı, bağlamsal ve kurumsal güçlerin belirlediği ve yönettiği meşru kuralları ve kaynakları içerir. Alanlar, baskın grup ile madun grubun iktidar, sermaye için mücadele ettiği yerlerdir (Swartz, 2002). Alan kavramını esnaflık araştırmalarında işlemselleştirmek yapısal güçleri sosyal, kurumsal ve örgütsel katmanlarda gün yüzüne taşımak anlamında faydalıdır (Tatlı ve ark., 2014, s. 62-63). Bourdieucu bakış açısı ilişkisel olarak yapılanmış güç ilişkilerinin yapılanmasına odaklanır. Bu yapılanma iş piyasasının sektörel yapısı, ekonomik dönüşümler, yasal düzenleyici çerçeveler, rekabet, güvenlik gibi etkenler tarafından şekillenir.
\end{abstract}

Bu bağlamda Türkiye Ekonomi Politikaları Araştırma Vakfı (TEPAV, 2018) Türkiye'deki Suriyeli girişimlerin büyüklüğünü ve performansını analiz etmek ve değerlendirmek için Gaziantep, Mersin, Hatay, Şanlıurfa, Kilis, Adana, Kahramanmaraş ve Mardin'de anket çalışması yapmıştır. Ankette ele alınan konular, altyapı, ticaret, finans, düzenlemeler, vergiler ve işletme ruhsatı almaktan, yolsuzluk, suç ve kayıt dış1lığa, işgücü piyasası entegrasyonuna ve iş yapma konusundaki engellere odaklanarak alanın yapısı üzerine bir çalışmaya örnektir. Araştırma kapsamına İstanbul gibi Türkiye'de en fazla Suriyeli barındıran (TEPAV, 2018) bir ilin alınmaması bir eksikliktir. TÜBİTAK tarafından desteklenen proje kapsamında yapılan alan çalışmalarından elde edilen verilere göre Suriye sınırına komşu illerde Arapça bilen Türkiye Cumhuriyeti vatandaşlarının yaşıyor olması Suriyeli girişimcilere ticari faaliyetlerinde kolaylık sağladığı yönündedir. Araştırma kapsamındaki illerle İstanbul arasındaki yapısal farklılıklar karşılaştırılması gereken bir araştırma konusudur.

Bir ülkenin iş piyasasındaki sektörel yapı, göçmenlerin iş olanaklarını belirleyen bir etken olarak önemlidir. Sektörel yapı bir ülkenin sınırları içinde de farklılıklar göstermekte, imalat sanayi ya da tarım iş̧̧isine yönelik talep bölgeden bölgeye değişmektedir. Göçmenlerin ücretli işçi olarak çalışabileceği sektörlerin varlığı, sektörlerin iş gücü arzını emebilme potansiyeli esnaflaşma motivasyonunu etkileyen bir faktördür. Örneğin, Türkiye'de yaşayan Suriyelilerin tekstil, inşaat, mobilya, atık 
kâğıt işçisi veya, mevsimlik tarım işçisi olarak (Bakioğlu, Artar ve İzmir, 2018) ücretli iş bulabilmeleri mümkündür. Gelişmiş kapitalist ekonomilerde imalat sanayisinde yaşanan sanayisizleşme ve de-regülasyon sonucu imalat sanayisinin ucuz iş gücünün olduğu bölgelere taşınmasıyla birlikte imalat sanayisinde göçmen emeğine duyulan arz azalmıştır (Karan, 2017). Makro yapısal faktörler sonucunda yeni gelen göçmenlerin karşılaştıkları firsatların yapısı da değişmektedir. Örneğin, sanayisizleşme ve deregülasyon politikalarına müteakiben, 1980'lerde İngiltere iş piyasasında meydana gelen dönüşümler sonucunda yaratılan "artık nüfus" kendi kendine yetebilen göçmen esnaf ruhu ile disiplin altına alınmaya çalışılmıştır. Bu politikalar şehir isyanlarını eşgüdümlü olarak gündeme getirilmiş, 1981 Brixton isyanının ardından küçük azınlıklara ait işletmelerin desteklenmesine yönelik politikalar sanayisizleşmenin ve de-regülasyonun olumsuz etkilerine karşı toplumsal güvenliği sağlamaya yönelik önlem olarak ortaya çıkmıştır (Lord Scarman, 1981, s. 11). Dolayısıyla, göçmen girişimciliğine dair firsatların yapısı yukarıdaki örnekte de tartışıldığı üzere tarihsel koşullara bağlı olarak şekillenir. Yukarıdaki bölümlerde tartışılan teorilerin ve analitik modellerin politik ekonomi gibi göçmenlerin iş olanaklarının firsatlar yapısını etkileyen makro yapısal etkenlere yeterli ilgiyi göstermediğini söyleyebilir (Collins, 2000, s. 13). Tatlı ve diğerleri (2014, s.64) bu konuda şunları şöyler:

....Girişimcilik eylemi, refah sistemlerinin çözüldüğü ve gelir seviyesindeki adaletsizlerin daha da derinleştiği dönemlerde cesaretlendirilmektedir. Fakat politik ekonomiyi verili ve sorunsuz olarak değerlerdiren bu bakış açısı girişimcilik ve küçük esnaf araştırmalarında genellikle eksiktir.

Geçici koruma kapsamında yer alan Suriyelilerin çalışmalarına ilişkin usul ve esaslar 2014 yılında resmi gazetede yayınlanan Çalışma ve Sosyal Güvenlik Bakanlığının teklifi üzerine Bakanlar Kurulunca belirlenmiştir.

$\mathrm{Bu}$ yönetmeliğe göre:

Geçici koruma kimlik belgesine sahip olanlar, Bakanlar Kurulunca belirlenecek sektörlerde, iş kollarında ve coğrafi alanlarda (il, ilçe veya köylerde) çalışma izni almak için Çalışma ve Sosyal Güvenlik Bakanlığına başvurabilir. Yabancıların çalışamayacağı iş ve mesleklere ilişkin mevzuatta yer alan hükümler saklıdır. Geçici korunanlara verilen çalışma izinlerinin süreleri, geçici korumanın süresinden fazla olamaz. Geçici koruma sona erdiğinde, bu kapsamda verilen çalışma izni sona erer. Geçici korunanlara verilen çalı̧̧ma izni, Kanunda düzenlenen ikamet izinleri yerine geçmez.

Karan'ın (2018; 2019) çalışmaları göstermektedir ki geçici koruma kapsamında kayıt yapılan ilden farklı bir ilde işletme işleten bir Suriyelinin işyeri Türkiye kökenli bir T.C. vatandaşına kayıtlıdır. Çünkü yönetmelik gereği girişimci adayı geçici koruma kapsamında kayıtlı olduğu ilde çalışma iznine sahip olabilmektedir. Kayıt olunan ilden 
farklı bir ilde iş yeri açmak isteyen bir girişimcinin iş yerini kendi adına kaydettirmesi mümkün olmadığından işletmeyi T.C. vatandaşının üzerine kaydettirmektedir. Ticaret sicil kaydı olmayıp faaliyet gösteren Suriyeli işletme sahiplerine kaydını T.C. vatandaşı üzerine yaptırmış Suriyeli işletme sahipleri de eklenince TOBB verilerine yansıyan Suriyeli işletme sayısının gerçek verileri yansıtmadığını söylemek mümkündür.

İşletme sahiplerinin diğer bir karşılaştıkları sorun ise seyahat haklarına getirilen kısıtlamalardır. Ticari faaliyetleri için seyahat etmek zorunda olan bir işletme sahibi sürekli valilikten izin almak zorunda kalmaktadır. Göç İdaresi Müdürü Bahçeci (Hürriyet, 2016) Suriyelilerin Türkiye içerisinde mobilitesini azaltmayı ve herkesin bulunduğu ilde ikametinde sabit kalmalarını sağlamayı amaçladıklarını belirtmiştir.

Benzer şekilde, ILO Türkiye Ofisi’nin (2016) "Suriyeli İşçi, İşveren ve Girişimcilerin İşüucü Piyasasında Karşılaş̧ıkları Sorunlar ve Çözüm Önerileri Çalıştayı Genel Değerlendirme" raporu Suriyeli girişimcilerin karşılaştıkları sorunları şu maddeler altında toplamaktadır: seyahat kısıtları, yasal düzenlemelerin uygulanmasındaki farklılıklar, mülkiyet hakkı, bankalarda hesap açma sorunu, diploma denklik sorunu, eğitim sorunu ve kamu hizmetlerinde yaşanan dil sorunu.

Sektörden sektöre farklılık gösterse de Suriyeli mülteci iş yeri sahiplerinin başarı şansını etkileyen önemli etkenlerden birisi hem Suriyeli işletmelerin kendi aralarında hem de aynı sektörlerde faaliyet yürüten yerli işletmelerle aşırı rekabet ortamıdır. Yerli işletmelerden farklı olarak etnik ürünler satan Suriyeli işletmeler göreceli olarak korunaklı bir piyasada faaliyet yürütürler. Suriyelilerin kültürel beğenilerine hitap eden yerli işletmenin bulunmayışı Suriyeli işletmeleri yerli işletmelerle doğrudan rekabet etmekten kurtarır. Örneğin, Suriyelilerin damak zevkine hitap eden restoranlar, bakkal, süpermarket gibi perakendeciler, toptancılar, Suriyelilerin tercihlerine uygun giyim mağazaları, Suriyelilerle yerli işletmeleri rekabet için karşı karşıya getirmez. Bu ürün ve hizmetleri talep edenler Suriyelilerle sınırlı kalır. İşletme sahipleri etnik ürün ve hizmetlerin kültürel kodunu bilmek zorundadır.

Kültürel kod bilgisi ve beğenisi gerektirmeyen ürün ve hizmetler, bütün bölgedeki tüketicilere hitap eder. Böyle bir durumda ise yerli işletmeler ile Suriyeli işletmeler rekabet için karşı karşıya gelir. Rekabet, iş yoğunluğuna, işletmelerin elde ettiği karın düşmesine, işyeri kapatmalara ve yerli işletme sahipleri ile Suriyeli işletme sahipleri arasında gerilime neden olur. Örneğin, berberlik ve taksicilik gibi hizmet sektöründe çalışan Suriyeliler, yerli esnafla aşırı rekabete girerek fiyatların ucuzlamasına neden olmuştur (Gaziantep27, 2017; Hürriyet, 2018; Sputnik, 2018).

Gaziantep Berberler Odası Başkanı Hacı Darıcı, Gaziantep’te kayıtlı 1300'ün üzerinde, kayitsız ise 200 'ün üzerinde berberlik yapan esnaf bulunduğunu belirtmiştir. Darıcı, sektördeki aşırı arzın fiyatların aşağı çekilmesine, Suriyelilerden de işyeri 
kapanmalarının yaşanmasına ve işletmelerin sürekli el değiştirmesine neden olduğunu dile getirip; çok ucuza iş yapan berberleri belediyelere, esnaf odalar birliğine bildirdiklerini ifade etmiştir (Gaziantep27, 2017).

İstanbul Umum Berberler Odas1 verilerine göre kent genelinde Suriyelilerin 81 kayıtlı işletmesi vardır. Bu sayı odaya göre kayıtsızlarla birlikte yüzü geçmektedir. Kayıt dışı çalışan berberlerin birçoğunun piyasanın altında kesim yaptığı ve Suriyelilerin yanı sıra birçok Türk vatandaşı da daha ucuz olduğu için Suriyeli berberleri tercih ettiği belirtilen açıklamada, Suriyeli işletme sahiplerinin yarı fiyatına saç ve sakal tıraşı yaptıkları vurgulanmıştır (Hürriyet, 2018). Başka bir haberde ise İstanbul'da Aksaray, Esenyurt, Bahçelievler, Bağcılar gibi semtlerde yoğunlaşan binlerce berberin vergi levhasız, belgesiz, kaçak çalıştığını, berberler odasının uyguladığı kurallara uymadıklarını oda başkanı tarafından belirtilmiştir (Sputnik Türkiye, 2018). Örneğin, bazı bölgelerde Pazar günleri berberlerin kapalı olması kararına uyulmadığı ve Suriyeli berberlerin dükkân açtıkları vurgulanmış ve yerli berberlerin işlerinin allak bullak olduğu açıklanmıştır.

Aksaray'da berber dükkânı işleten Türkiye kökenli Turgay Gül ise eskiden tüm çalışanlarının Türk olduğunu ancak son dönemde yoğunlaşan Iraklı, Suriyeli ve Arap müşterilerinden dolayı çalışanlarının hepsinin Suriyeli olduğunu belirtmiştir. Gül, "şu an çalışanlarımın çoğu Suriyeli, hem daha ucuza çalışıyorlar hem de müşterilerimizin dilinden anlıyorlar. İki taraf da memnun. Ben de paramı kazanıyorum” demiştir (Sputnik Türkiye, 2018).

Aşırı rekabetin yaşandığı bir diğer hizmet sektörü ise taksiciliktir. Türkiye'de uzun süre tartışılan UBER' in ardından Ankara Altındağ' $1 n$ Önder ve Ulubey mahallelerinde "korsan" taşımacıllk yapan ve 45 TL'lik yere 25 TL alan Suriyeli mültecilerin Ankara Emniyet Müdürlüğü’ne ve Ankara Umum Otomobilciler ve Şoförler Esnaf Odası'na defalarca şikâyet edildiği belirtilmiştir (Sputnik Türkiye, 2018).

\section{Habitus}

Habitus bireylerin bir alanla ilişkili olarak toplumsal dünyanın algılanışına dair edindikleri zihinsel yapılar ve içselleştirilmiş yapılardır. Bourdieu'nun habitus kavramı eserlerinde farklı tanımlar içerir. En bilinen tanımsa şudur:

Belli bir varoluş koşulu sınıfıyla ilişkilenen şartlanmalar habituslar üretir. Bunlar sürdürülebilir ve aktarılabilir eğilimler sistemleri, yapılandırıcı yapılar olarak işleme eğilimi içinde yapılandırılmış yapılardır. Yani, amacın ve bu amaca ulaşmak için gerekli işlemlerin bilincinde olunduğunu varsaymadan, nesnel bir şekilde amaçlarına uyumlu olan pratikleri ve tasarımları oluşturan ve düzenleyen ilkelerdir bunlar (Bourdieu, 1980, s.88'den akt., Jourdain ve Naulin, 2016). 
Bunlar dayanıklı ve aktarılabilir kemikleşmiş eğilimler sistemini oluşturur (Bourdieu, 1990). Habitus, bireylerin sosyalleştikleri süre içinde geçmişte içselleşmiş ve benimsemiş oldukları idrak (dünyanın nasıl algılanacağına dair), değerlendirme (nasıl değerlendirileceğine dair), ve eylem (nasıl davranılacağına dair) şablonlarından meydana gelir. Habitus, fail ile yapı arasında aracılık eder. Habitus, bireysel eylem ile makro yapısal süreçleri bağlamada güçlü bir araç olarak görülebileceği gibi bir alandan diğerine geçen bireyin eski alanlarını yeni alanlara bağlar.

Türkiye'deki Suriyelilerin esnaflaşması üzerine az sayıda yapılan araştırmalardan birisi de Ataş’ın "Suriyeli Sı̆̆ınmacıların İş Kurma Süreci: Laleli-Beyazıt Çevresi”" başlıklı çalışmasıdır. Ataş (2017) çalışmasında Laleli bölgesinde küçük işletme açan Suriyelilerin Suriye'de de benzer işler yaptıklarını bulgulamıştır. Benzer şekilde Deniz (2017), Hatay, Gaziantep ve Mersin illerinde 30 girişimci ile yaptı̆̆ı görüşmede 26'sını Suriye'de de esnaflık yaptığını bulgulamıştır. Suriyelilerin ana vatanlarında elde ettikleri yatkınlıklar, eğilimler Türkiye'deki ekonomik alan tercihlerinde etkili olmaktadır. Suriyelilerin ana vatanlarındaki geçmişlerinde girmiş oldukları ekonomik alandaki sektörler habituslarını oluşturup, Türkiye'ye aktardıkları yatkınlıkları ve eylem şablonlarını meydana getirmektedir.

\section{Sermaye Türleri}

Bourdieu'nun sermaye türleri, katmanlaşmış toplumlarda çatışma ve güç ilişkilerini işaret eder. Bourdieu dört çeşit sermaye türü tanımlar. "Ekonomik sermaye”, hemen ve doğrudan paraya dönüştürebilen kaynaklardır. "Kültürel sermaye" üç alt türe ayrılır. Bunlar, bireye gömülü, kurumsal ve nesneleşmiş kültürel sermayelerdir. Bireye gömülü kültürel sermaye türü, köklü bir geçmişe dayanan zihnin ve bedenin yatkınlıklarıdır: şive, lehçe, vücut dili gibi. Nesneleşmiş kültürel sermaye kitapları, makinaları, sözlükleri, antikaları, resim tablolarını içerir. Son olarak kurumsallaştırılmış kültürel sermaye türü diplomalar, sertifikalar gibi eğitime dair yeterlilik belgelerini içerir. Bunlara ek olarak kültürel sermaye enformel becerileri, aileden, arkadaşlık gruplarından ve sivil toplum kuruluşlarından elde edilen yetenekleri de içerir. "Sosyal sermaye" bireyin kendi çıkarlarını gerçekleştirmek üzere aktive edebileceği sosyal ilişkilerdir. Son olarak "sembolik sermaye" esnafin belli bir alandaki kuralları değiştirebilmek ve politikaları belirleyebilmek için sahip olduğu politik gücü, toplumsal statüsü ve toplumdaki etkisidir. Sembolik sermaye diğer sermaye türlerinin birleşimidir (Özbilgin ve Tatlı, 2005; Özkan-Karataş ve Chell, 2015). Bourdieucu bir bakış açısı, sermaye türlerinin oluşumunu ve yeniden üretimini araştırmaya olanak verir. Aktörler bir alanla ilişkili olan sermaye türlerine yatırım yaparak sınıfsal yapıdaki göreceli pozisyonlarını geliştirmeyi amaçlarlar. Sermaye türleri bir alanda oluşturulur. Bir alan olmadan sermayeden de söz etmek mümkün değildir. Sermaye türleri bireylere eşit dağı(tı)lmaz ve bireyler bir sermaye türünü başka bir sermaye türüne dönüştürebilirler (Swartz, 
1997, s.74). Aşağıdaki bölümlerde Suriyeli küçük işletme sahiplerinin sözü edilen sermaye biçimlerini nasıl aktive ettikleri ve birbirine dönüştürdükleri tartışılacaktır.

\section{Ekonomik sermayeye dönüssen sosyal ve kültürel sermaye}

Bu bölüm sosyal ve kültürel sermayenin ekonomik sermaye elde etmek için nasıl aktive edildiğine ve oluşturulduğuna odaklanmaktadır. Kültürel ve sosyal sermayenin nasıl da ekonomik sermayeye dönüştürülebileceği tartışılacaktır.

Küçük işletme sahibi adaylar birikimlerinden faydalandığı gibi, akrabalarından ve hemşerilerinden kaynak temin edebilmektedirler. Aktive edebildikleri sosyal ağlardan elde edilen kaynaklar ekonomik sermaye elde etmede en önemli sosyal sermaye kaynaklarından birisidir. Dolayısı ile Türkiye'de işletme açmak için yeterli ekonomik sermeye ve ekonomik sermaye temin etmek üzere aktive edilebilecek geniş bir sosyal sermayeye sahip olmayan işletme sahibi (adaylar) girişimcilik sürecinde, hem işletme açmada ve hem de işletmenin işleyişinde zorluklarla karşılaşırlar. Bourdieu'nun kavramsal çerçevesinde sermaye formları, bir sermaye formunun nasıl başka bir forma dönüştürüldüğünü anlamamıza olanak sağlar. Geniş ailenin dayanışmacı ilişkilerinden mahrum kalan ve anavatan ağları zayıf olan göç edilen ülkenin dilini bilen eğitimli göçmenler, aracılık yapıp açtıkları işyerlerini uygun sermayesi olan göçmenlere devretmeleri mümkündür. Boş mekânları küçük bir işletmeye çevirmek için fazla sermayeye ihtiyaç duyulmaz. Küçük işletme sahibi olmak için bilgisi ve becerisi olmayan; işyeri açma izni için gerekli bürokratik işletmeleri yürütecek kültürel sermayeden yoksun, açılan dükkânı dekore etme bilgisi olmayan, ucuz ve kaliteli malların nereden temin edilebileceğini bilmeyen Suriyeliler bu hizmetleri kendi dillerini bilen eğitimli Suriyelilerden alabilirler. Dolayısıyla, bu hizmetler için bir talep oluşur. Türkiye'de yaşayan Suriyeli esnaf adayı mültecilerin geniş sosyal sermaye hacimlerini soydaşlarının kültürel sermayeleriyle değiştirmeleri mümkündür. Etkin bir şekilde seferber edilecek etnik ağların büyüklüğü ekonomik sermaye temininde hacim açısında zenginken, kalite bakımından zayıf olabilmektedir. Böylece, sosyal sermayesi fazla olanlar kültürel sermaye satın alırlar. Aracılar ise kültürel sermayelerinden ekonomik sermaye çıkartırlar. Her bir girişımci adayının sahip olduğu sosyal sermayedeki hacim ve kalite toplumsal sınıf farklılıklarını işaretler. Böylece, bireylerin hacim ve kaliteleri farklı ekonomik, sosyal, kültürel sermaye portföylerini ve işyeri açmalarının farklı stratejilerini karşılaştırırken Bourdieu'nun bireysel temelli sermaye türlerini örneklendirmek mümkündür.

Mültecilerin arasındaki dayanışma her zaman sorunsuz olmaz. Ortaklıklar, verilen borcun geri dönmemesi ve benzer bir işletmenin hâlihazırda var olan bir işletmenin yanına açılması sebebiyle çeşitli çatışma konuları ortaya çıkar. Bu tür çatışma konularının genelde çözüme kavuşturulması dayanışma ilişkilerinin devamını sağlaması bakımından mülteci işletme sahiplerinin kolektif çıkarıdır. Örneğin, hemşeriye faizsiz 
sağlanan borcun zamanında geri ödenmesi gelecekte de benzer sorunlar yaşayabilecek bir işletme sahibinin başvurabileceği bir hemşeriyi sağlar. Borcun geri dönmemesi durumunda yaşanan anlaşmazlıkların çözümü konusunda mültecilerin kendi aralarında saygın, güvenilir kişilerden oluşturdukları hukuki mekanizmalar yaşanan sorunların çözümünde etkili olabilmektedir.

Anlaşmazlık çözümü meclisinin aldığı kararlara uyulmaması genellikle rastlanılan bir durum değildir. Çünkü bu meclislere mültecilerin duyduğu güven, meclisin aldığ 1 karara riayet etmenin sağladığı fayda ve uygulanmasa dahi olası yaptırım tehdidi sosyal ağlara duyulan güveni destekler. Yaptırımların gücü uygulanmalarından değil de tehdidinden kaynaklanır (Henry, 2004). Yaptırımlar, aforoz edilme, damgalanma, kovulma, para cezasın ödemeye zorlamayı içerir. Mülteci dernekleri çatışan taraflar arasında aracı rolü oynar. Mülteciler derneklere güven duyar ve kararlarına saygı gösterir.

Dahası, göçmenlerin kurdukları dernekler göçmenlerin yeni toplumlarına uyum ve entegrasyon sürecinde dayanışma ağlarını oluşturan ikincil ilişkileridir (Adıgüzel, 2013). İs, barınacak yer bulma, tercümanlık, hukuk hizmeti sağlama vb. sorunlarda göçmenler derneklerden faydalanırlar.

Dolayısıyla, mülteci derneğine üye olmak bir sosyal sermaye türü olarak çatışan tarafların hak arayabilecekleri bir platform sağlar. Aforoz gibi bir yaptırımın inanılmaz yıkıcı sonuçları olabilmektedir. Çünkü borçlu kişinin sosyal ilişkileri ve ekonomik refahı hemşeri ağlarına bağlıdır. Bunun sebebi, büyük oranda mülteciler arasında oluşan güçlü sosyal sermaye olmakla birlikte mültecilerle eski yerleşikler arasındaki ilişkilerin zayıf olmasından kaynaklanır. Anlaşmazlık çözümü meclisleri mültecilerin kendi aralarında dayanışmalarından doğabilecek riskleri azaltır. Mültecilerin birbirlerine duydukları güveni destekler.

Esnaf adaylarının karşılaştığı sorunlar işyeri açmak için gerekli olan sermayeyi temin etmekle bitmez. Esnaf adayları olası seçenekler hakkında bilgiye gereksinim duyarlar. Aşağıdaki bölüm sosyal ağların bilgiye (kültürel sermayeye) ulaşmadaki rolü hakkındadır.

\section{Kültürel sermayeye dönüşen sosyal sermaye}

Göçmenlerin oluşturduğu dernekler ya da göçmenlere yönelik örgütler sağlık, sosyal hizmetler, oturum izni, barınma, esnafların karşılaştıkları sorunların çözümü, yasal haklar gibi çok farklı konularda bilgilendirici toplantılar yaparak Suriyelilerin kendi dillerinde bilgi edinmesinin araçlarından birisidir. Suriyelilerin buluştuğu dernekler, kahvehaneler esnaf adaylarının çeşitli konularda bilgi edinebileceği sosyal platformlardır. Bu sosyal platformlar Türkiye'deki göçmen girişimcilerin ihtiyaç duyduğu kültürel sermaye eksikliğini giderici faaliyetlerle göçmenlerin yararlanabileceği önemli bir sosyal sermaye kaynağıdır. 
Örneğin, Avrupa Komisyonu ve İngiliz Ulusal Ajansı tarafından desteklenen “Avrupa'daki Vasıflı Göçmenlerin Girişimcilik ve Kurumsal Girişimcilik üzerine Becerilerinin Geliştirilmesi Projesi” kapsamında gerçekleştirdiği "Türkiye'deki Göçmen Girişimciliği Üzerine bir Araştırma” çıktısı benzer şekilde göçmenlerin kültürel sermayelerindeki eksikliklerine 1şık tutmaktadır (MAKRO Yönetim Geliştirme Danışmanlık Şirketi, 2018). Bulgulara göre göçmenlerin Türkçe dil bilgisi, ticari mevzuat bilgisi ve iletişim konularında eğitime, ağ kurma, yaratıcı düşünme ve problem çözme konularında desteğe ihtiyaçları vardır.

Esnaf adayları bir iş yeri açmadan önce yatırım maliyetini ve kar marjını hesaplamak zorundadırlar. Olası kar marjları hakkında güvenilir bilgiye ihtiyaç duyarlar. Bu tür bilgilerin teminini yakın, birbirine kenetlenmiş ağlar sağlar. Suriyelilerin kendi dillerinde çıkan gazeteler, sosyal medya platformları benzer şekilde birçok konuda esnaf adaylarına bilgilendirme sağlar. Esnaf adaylarına destek hizmeti sağlayan kişilerin iletişim bilgileri bu yolla temin edilebilir.

Sonuç olarak Bourdieu sosyolojisinin sosyal sermaye kavramı, Suriyeli mültecilerin nasıl resmi ve enformel ağları aktive ederek genel sosyal hizmetlerden iş ile ilgili çok farklı konularda bilgi erişimi sağladığını açıklar. Sosyal ağlardan faydalanılarak ağızdan ağıza yayılan bilgi, göçmen dernekleri, arkadaş tavsiyeleri ve gazeteler farklı konularda mültecilerin bilgilenmesini sağlar.

Beceriler, eğitim ve iş deneyimi yeni kurulan işletmelerin sahipleri için önemli kültürel sermaye biçimidirler. Birçok Suriyeli mültecinin Suriye'de küçük işletme sahipliği deneyimi bulunmaz. Esnaflık becerisi ve eğitimi iki şekilde elde edilebilir: Resmi eğitim almak ilk yoldur. Resmi eğitim bir işletmede alınan resmi akademik eğitim olabildiği gibi, kısa bir dönem süren eğitici kurslar da olabilir. İş deneyimi kazanmanın ikinci yolu ailenin veya hemşerilerin işletmeleridir. Aile veya hemşeri işletmesinde çalışmak aynı sektörde kendi hesabına çalışmak için atılmış bir adımdır. Kendi hesabına çalışmak için gerekli olan becerilerin kazanımı için atılan adım açılacak olan işletmelerin sermaye ihtiyacını karşılamak için de gereklidir. Benzer şekilde, işçinin kendi işini kurana kadar sömürülmesi patronaj ilişkisidir. İşyeri sahibi hemşerisi ya da akrabaları ucuza kalacak yer ve yemek karşılı̆̆ı işçinin emeğini sömürürler.

Küçük işletmelerde çocuk emeğinin yaygın kullanımı ve sömürüsü sadece finansal sebeplerle gerçekleşmez. Aynı zamanda, çocuklar işletme içinde çevirmenlik ve ara buluculuk rolleri de üstlenirler (Song, 1999). Ebeveynler, esnaf olmanın bir özelliği olan iyi müşteri ilişkileri kurmanın gereği olarak çocuklarının emeğine ihtiyaç duyarlar. Daimi müşterilerle sohbet etmek, müşterilerin ne istediklerini anlamak ve bazen de müşterilerin sorunlarını dinlemek işin bir parçasıdır. Müşterilerle iyi ilişki kurmanın yolu olarak çocukların kültürel sermayesinden faydalanılır. Dolayısıyla, akrabalık ilişkilerinin sağladığı sosyal sermaye aile içerisinde sosyal sermayeye dönüşür. 
Son olarak, işyeri ruhsatı ve sağlığa uygunluk sertifikasının temini gibi konularda bürokratik işlemleri halledebilecek uzman kişilerin ve tercümanların hizmeti işletmelerin kuruluşunda elzemdir. Bu konularda hizmet sağlayan aracı mülteciler kültürel sermayelerini kullanarak ekonomik sermaye elde ederler. Çünkü işletme açmak isteyen mülteciler işyeri açmak için ve lisans başvurusunda bulunmak için yeterli kültürel sermayeye sahip değillerdir.

Sonuç olarak, esnaf adaylarının ya da hâlihazırda esnaf olan mülteciler sosyal ağlarını aktifleştirerek sosyal sermayelerini sertifika, ruhsat, işletme becerileri ve eğitim gibi kültürel sermaye biçimlerini elde etmek için kullanırlar.

\section{Sembolik sermaye}

Sembolik sermaye, mültecilerin yeni yaşadıkları ülkede herhangi bir konuda kendi yaşam koşullarını iyileştirmek amacıyla sahip oldukları politik güç, statü ve toplumdaki nüfuzdur. Bu bağlamda sembolik sermaye mülteci esnafların çalışma koşullarında iyileştirme sağlamak amacıyla faydalanılan sermayedir. Mültecilerin kendi seslerini duyurmasında ortaya çıkan politik firsatların ve engellerin yapısı, esnafların ihtiyaçlarını duyurmaları sahip olunan sembolik sermaye tarafından şekillenir. Dolayısıyla, aynı sektörlerde rekabet edilen büyük şirketlerin sahip olduğu sembolik sermaye sektördeki dominant konumlarını yeniden üretmelerinin aracıdır.

Özatalay’ın (2012, s. 69) belirttiği üzere bu noktada devletle kurulan ilişkiler ön plana çıkar. Sembolik sermayesi yüksek şirketler devlet iktidarına nüfuz ederek kendi çıkarlarına uygun mevzuat çıkarılması ve mülkiyet haklarına sahip olunması bakımından etkileyebilirler. Dahası, sembolik sermaye "devlet teşviklerinden, özel vergi tarifelerinden, AR-GE desteklerinden, devlet ihalelerinden vb. yararlanmak konusunda avantaj elde etmek" (Özatalay, 2012, s. 69) için aktive edilir.

Mültecilerin ana-akım politik kanallarla seslerini etkili bir şekilde duyurmaları genellikle mümkün değildir. Bunun sebebi, mültecilerin Türkiye toplumuyla kurabildikleri zayıf sosyal ağlardır. Bourdieu'nun belirttiği üzere, “zengin sembolik sermaye sahibi, nobiles (etimolojik olarak herkesin tanıdığı, saydı̆̆ı üst sınıfa mensup kişiler, soylular), kendi çıkarlarına uygun değerleri kabul ettirecek konumdadırlar. Çünkü bilhassa, bizim toplumlarımızda kurumlar üzerinde pratik fiili tekelleri vardır” (Bourdieu, 1989, s. 21). Mülteci esnaflar ile yerleşik büyük şirketler arasındaki güç farkı sebebiyle yerleşik şirketlerin alanın kurallarını belirleme potansiyeli daha fazladır. Mülteci esnafların çeşitli konularda sorunları olmasına rağmen sahip oldukları düşük sembolik sermaye sebebiyle karar yapıcılara etki kapasiteleri azdir. 


\section{Sonuç Yerine: Bourdieu Sosyolojisinin Avantajları}

İlk olarak, Bourdieu'nun alan, habitus ve sermaye türleri kavramları göçmen esnafların karşılaştıkları dinamikleri anlamakta bütüncül ve çok katmanlı bir perspektif sunmaktadır. Bu üç, makro, mezo ve mikro ölçekler birbirleriyle ilişki içindedirler ve birbirlerinden bağımsız şekillenmezler. Örneğin, alanın yapısı göçmen girişimci adaylarının ve hâlihazırda faaliyette bulunan girişimcilerin oluşturmak ve aktive etmek zorunda oldukları sermaye türlerini (ekonomik, kültürel, sosyal ve sembolik) etkiler. Dolayısıyla, ölçeklerden birisine odaklanan kuramsal bir çerçevenin ve alan çalışmasının bütüncül bir perspektif sağlaması mümkün olmadığı gibi göçmen girişimciliğinin dinamiklerini açıklayıcı niteliği de yoktur.

Alan kavramı, Türkiye özelinde küresel politik ekonomiyi, Türkiye'deki sektörel yapıyı, yasal düzenlemeleri, alanda rekabet edilen diğer aktörleri, güvenlik konularını tartışmaya olanak sağlamaktadır. Habitus kavramı göçmen esnafların Türkiye'deki sosyal yapıları nasıl algıladıklarını tartışma olanağı sağladığı gibi, geldikleri ülkelerden taşıdıkları yatkınlıkları Türkiye'de nasıl esnaflıkla ilişkilendirdiklerini anlamamıza olanak verir. Oluşturulan, aktive edilen ve dönüştürülen sermaye formları ise göçmen esnafların alanda karşılaştıkları çeşitli sorunları hangi yollarla çözmeye çalıştıklarını açıklamaya yardımcı olur. Bu kavramlar birbirleriyle ilişkilidir.

Örneğin, Suriyeli göçmen girişimci sermaye türlerinin mobilize edilmesinin, bir sermaye formunun diğerine dönüşebilmesinin ve var olabilmelerinin ön koşulu göçmen girişimcilerinin girebileceği bir alanın var olmasıyla mümkündür. Sermayeler hazır bulunmaz; Suriyelilerin bavullarından hazır bir şekilde çıkmazlar. Dahası Suriyelilere sermaye türleri nitelik ve hacim açısından eşit bir şekilde dağılmazlar. İş yeri açmak ve iş yerinin faaliyetlerini sürdürebilmek için göç edilen ülkede aktive edilmeleri ve birbirine dönüşen sermaye formlarıyla oluşturulmaları gerekir. Bütün bu süreçler incelenmesi gereken alan araştırmalarının problemleridir.

Hakem Değerlendirmesi: Dış bağımsız.

Çıkar Çatışması: Yazar çıkar çatışması bildirmemiştir.

Finansal Destek: Bu çalı̧̧ma 117K826 kodlu "Kentsel Mültecilerin Adaptasyon ve Uyum Süreçlerine Yeni Bir Bakış Açısı: Kapsayııı Kent İnşası Amaçlı Sosyal İnovasyon Deneyi” başlıklı proje kapsamında TÜBİTAK (1003) programı tarafından desteklenmektedir.

Peer-review: Externally peer-reviewed.

Conflict of Interest: The author has no conflict of interest to declare.

Grand Support: This study is supported by TÜBITAK (1003) program within the scope of the project titled "A New Perspective on Adaptation and Adaptation Processes of Urban Refugees: Inclusive City Construction Purpose” (Project number 117k826). 


\section{Kaynakça/References}

Adıgüzel, Y. (2013). Dayanışma ağları üzerinden Eskişehir'de siyaset ve göçmenlik algısı. Sosyoloji Dergisi, 2, 73-94.

Altinay, L., \& Altinay, E. (2006). Determinants of ethnic minority entrepreneurial growth in the catering sector. The Service Industries Journal, 6, 203-221.

Aldrich, H., Cater, J., \& Jones, T. (1981). Business development and self-segregation: Asian enterprise in three British cities. In C. Robinson, V. Smith, \& S. Peach (Eds.), Ethnic segregation in cities (pp. 170-190). London, UK: Croom Helm.

Ataş, Ö. (2017). Suriyeli sığınmacıların iş kurma süreci: Laleli Beyazıt çevresi (Yüksek lisans tezi, İstanbul Ticaret Üniversitesi, Sosyal Bilimler Enstitüsü, Uluslararası İlişkiler Bölümü, İstanbul). https://tez.yok.gov.tr/UlusalTezMerkezi/ adresinden edinilmiştir.

Bakioğlu, A. Artar, F., \& İzmir, H. (2018). Ankarada'daki Suriyelilerin mültecilik deneyimleri: Göç, gündelik yaşam, geçim deneyimleri ve sosyal dışlanma. Ankara: Ankara Sosyoloji Derneği.

Basch, L. G., Glick-Schiller, N., \& Szanton-Blanc, C. (1994). Nations unbound: Transnational projects, postcolonial predicaments, and deterritorialized nation-states. Amsterdam: Gordon and Breach.

Basu, A., \& Altınay, E. (2002). The interaction between culture and entrepreneurship in London's 1mmigrant business. International Small Business Journal, 20, 371-394.

Bonacich, E. (1973). A theory of middleman minorities. American Sociological Review, 38, 583-594.

Bonacich, E. (1987). 'Making it' in America: A social evolution of the ethics of 1mmigrant entrepreneurship. Social Perspectives, 30, 446-466

Bonacich, E., \& Modell, J. (1980). The economic basis of ethnic solidarity: Small business in the Japanese American community. Berkeley, CA: University of California Press.

Bourdieu, P. (1986). The forms of capital. In J. G. Richardson (Ed.) Handbook of theory and research for the sociology of education (pp. 46-58). New York, NY: Greenwood.

Bourdieu, P. (1987). What makes a social class? On the theoretical and practical existence of groups. Berkeley Journal of Sociology, 32, 1-17.

Bourdieu, P. (1989). Social space and symbolic power. Sociological Theory, 7, 14-25.

Bourdieu, P. (1990). The logic of practice. Stanford, CA: Stanford University Press.

Bourdieu, P., \& Wacquant, L. J. D. (1992). An invitation to reflective sociology. Cambridge, MA: Polity Press.

Cassarino, J.-P. (1997). The theories of ethnic entrepreneurship, and alternative arguments of social action and network analysis. Florence, Italy: EUISPS Working Papers.

Collins, J. (2000). Ethnicity, gender and Australian entrepreneurs: Rethinking Marxist views on small business. Journal of Social Change and Critical Inquiry, 2, 137-149.

Deniz, D. (2017). Türkiye'deki Suriyeli mülteci girişimcilerin oluşum süreci ve özellikleri (Yüksek lisans tezi, Mustafa Kemal Üniversitesi, Sosyal Bilimler Enstitüsü İşletme Ana Bilim Dal1, Hatay).

Drori, I., \& Lerner, M. (2002). The dynamics of limited breaking out: The case of the Arab manufacturing businesses in Israel. Entrepreneurship and Regional Development, 14, 135154.

Emirbayer, M., \& Johnson, V. (2008). Bourdieu and organizational analysis. Theory and Society, $37,1-44$. 
Engelen, E. (2001). Breaking-in and breaking-out: A Weberian approach to entrepreneurial opportunities. Journal of Ethnic and Migration Studies, 27, 203-223.

Esping-Andersen, G. (1990). The three worlds of welfare capitalism. Cambridge, MA: Polity.

Esping-Andersen, G. (1999). Social foundations of postindustrial economies. Oxford, UK: Oxford University Press.

Gaziantep27. (2017, January 17). 138 korsan Suriyeli berber var. https://www.gaziantep27.net/138korsan-suriyeli-berber-var-500569h.htm adresinden edinilmiştir.

Gold, S. J. (2010). The store in the hood: A century of ethnic business and conflict. Lanham, MD: Rowman \& Littlefield Publishers.

Harvey, D. (1989). The condition of postmodernity. Oxford, UK: Blackwell.

Henry, L. (2004). Citizenship, morality and participatory development: The case of Sebat Bet Gurage. In G. Mohan \& S. Hickey (Eds.), Participation from tyranny to transformation (pp. 140-156). London, UK: Zed.

Hürriyet. (2016, 16 Mart). Suriyeli sığınmacılara "seyahat izin belgesi” uygulaması. http://www. hurriyet.com.tr/suriyeli-siginmacilara-seyahat-izin-belgesi-uygulamasi-37259266 adresinden edinilmiştir.

Hürriyet. (2018, 7 Ağustos). İstanbul'da yarl fiyatına Suriyeli berber. http://www.hurriyet.com.tr/ istanbulda-yari-fiyatina-suriyeli-berber-40920900 adresinden edinilmiştir.

ILO Türkiye Ofisi. (2016). Suriyeli işçi, işveren ve girişimcileirn işgücü piyasasında karşılaştıkları sornlar ve çözüm önerileri çalıştayı genel değerlendirme. Ankara, Turkey: ILO Türkiye Ofisi Çalıştay Raporu.

Karan, O. (2017). Economic survival strategies of Turkish migrants in London. London, UK: Transnational Press London.

Karatas-Ozkan, M., \& Chell, E. (2015). Gender inequalities in academic innovation and enterprise: A Bourdieuian analysis. British Journal of Management, 26, 109-125.

Kayalar, M., \& Yıldız, S. (2017). Uluslararası göç sonrası ortaya çıkan girişimcilik türleri. Süleyman Demirel Üniversitesi İktisadi ve İdari Bilimler Fakültei Dergisi, 22, 55-62

Kloosterman, R., \& Rath, J. (2001). Immigrant entrepreneurs in advanced economies: Mixed embeddedness further explored. Special issue on immigrant entrepreneurship. Journal of Ethnic and Migration Studies, 27, 189-202

Kloosterman, R., \& Rath, J. (2003). Immigrant entrepreneurs: Venturing abroad in the age of globalization. Oxford/New York: Berg.

Kloosterman, R., van der Leun, J., \& Rath, J. (1999). Mixed embeddedness, migrant entrepreneurship and informal economic activities. International Journal of Urban and Regional Research, 23, 253-267.

Landolt, P. (2001). Salvadoran economic transnationalism: Embedded strategies for household maintenance, immigrant incorporation and entrepreneurial expansion [Special Issue]. New Research and Theory on Immigrant Transnationalism, 1, 217-242.

Light, I. (1972). Ethnic enterprise in America: Business and welfare among Chinese, Japanese, and Blacks. Berkeley, CA: University of California Press.

Light, I., \& Bonacich, E. (1988). Immigrant entrepreneurs: Koreans in Los Angeles. Los Angeles, CA. University of California Press. 
Light, I., \& Gold, S. J. (2000). Ethnic economies. San Diego, CA: Academic Press.

MAKRO Yönetim Geliştirme Danışmanlık Şirketi. (2018). Türkiye'deki göçmen girişimciliği üzerine bir araştırma (Avrupa'daki Vasıflı Göçmenlerin Girişimcilik ve Kurumsal Girişimcilik üzerine Becerilerinin Geliştirilmesi Projesi, Ankara, Turkey).

McEvoy, D., \& Hafeez, K. (2009). Ethnic enclaves or middleman minority? Regional patterns of ethnic minority entrepreneurship in Britain. International Journal of Business and Globalisation, $3,94-110$.

Min, P. G. (2008). Ethnic solidarity for economic survival: Korean greengrocers in New York City. New York, NY: Russell Sage Foundation.

Mülteci Derneği. (2019, October 17). Türkiyedeki Suriyeli sayısı Ekim 2019. Retrieved from https:// multeciler.org.tr/turkiyedeki-suriyeli-sayisi/ adresinden edinilmiştir.

Özatalay, C. (2012). Ekonomi teorisi ile ilişki içinde Bourdieu: Bir komprodor mu, bir eleştirmen mi? Sosyoloji Dergisi, 25, 57-83.

Özbilgin, M., \& Tatl1, A. (2005). Book review essay: Understanding Bourdieu's contribution to organisation and management studies. Academy of Management Review, 30, 855-877.

Özservet, Y. Ç. (2017). İstanbul'da girişimci göçmenler, 2017. İstanbul, Turkey: Marmara Üniversitesi Kent Sorunları ve Yerel Yönetimler Araştırma ve Uygulama Merkezi. https://dx.doi.org/10.13140/ RG.2.2.34018.43201

Pang, C. L., \& Rath J. (2006). The force of regulation in the land of the free: The persistence of Chinatown, Washington D.C. as a symbolic ethnic enclave. In M. Lounsbury \& M. Ruef (eds.), 2006 Volume of research in the sociology of organizations (pp. 195-220). Greenwich, CT: JAI Press.

Pécoud, A. (2004). Do immigrants have a business culture? The political epistemology of fieldwork in Berlin's Turkish economy. Journal of the Society for the Anthropology of Europe, 4, 19-25.

Portes, A. (2001) Introduction: The debates and significance of immigrant transnationalism. Global Networks, 1, 181-194.

Portes, A., \& Bach, R. L.. (1985). Latin journey: Cuban and Mexican immigrants in the United States. Berkeley, CA: University of California Press.

Portes, A., \& Manning R. D. (1986). The 1mmigrant enclave: Theory and empirical examples. In S. Olzak \& J. Nagel (Eds.), Competitive Ethnic Relations (pp. 47-68). New York, NY: Academic Press.

Ram, M., \& Jones, T. (2008). Ethnic minority business: Review of research and policy. Environment and Planning C: Government and Policy, 26, 352-374.

Rath, J. (2007, January). The transformation of ethnic neighborhoods into places of leisure and consumption (Working Paper 144). University of San Diego, Center for Comparative Immigration Studies (CCIS), San Diego, CA.

Scarman, L. J. (1981). The Brixton Disorders, 10-12th April. London: HMSO.

Siu, P. C. P. (1952) The Sojourner. American Journal of Sociology, 58, 34-44.

Song, M. (1999). Helping out: Children's labor in ethnic business. Philadelphia, PA: Temple University Press.

Sputnik Türkiye. (2018, July 5). Suriyeli berberler, yerli esnafi zora soktu. https://tr.sputniknews. com/turkiye/201807051034157316-suriyeli-berber-esnaf/?utm_source=https://t.co/ JpiAGV6230\&utm_medium=short_url\&utm_content=hXf6\&utm_campaign=URL_shortening adresinden edinilmiştir. 
Srinivasan, S. (1995). The South Asian petite bourgeoisie in Britain. Aldershot, UK: Avebury.

Tatl1, A., Vassilopoulou, J., \& Ozbilgin, M. F. (2014). A Bourdieuan relational perspective for entrepreneurship research. Journal of Small Business Management, 52, 54-69.

Türkiye Ekonomi Politikaları Araştırma Vakf1. (2018). Syrian entrepreneurship and refugee start-ups in Turkey: Leveraging the Turkish experience. TEPAV. Ankara: European Bank for Reconstruction and Development. https://www.tepav.org.tr/upload/files/1566830992-6.TEPAV_and_EBRD

Syrian_Entrepreneurship_and_Refugee_Start_ups_in_Turkey_Lever....pdf adresinden edinilmiştir.

Terjesen, S., \& Elam, A. (2009). Transnational entrepreneurs' venture internationalisation strategies: A practice theory approach. Entrepreneurship: Theory and Practice, 33, 1093-1120.

Terzano, K. R. (2010). Demographic change and neighbourhood satisfaction: The case of Little Italy, Cleveland. Policy \& The Environment, 41, 45-50.

Türkiye Odalar ve Borsalar Birliği. (2019, May). Kurulan/kapanan şirket istatistikleri. http://www. tobb.org.tr/BilgiErisimMudurlugu/Sayfalar/KurulanKapananSirketistatistikleri.php adresinden edinilmiştir.

Volary, T. (2007). Ethnic entrepreneurship: A theoretical framework. In L-P. Dana (Ed.), Handbook of research on ethnic entrepreneurship: A co-evolutionary view on resource management (pp. 30-41). Northampton, VT: Edward Elgar Publishing.

Waldinger, R. (1989). Structural opportunity or ethnic advantage? Immigrant business development in New York. International Migration Review, 23(1), 48-72.

Waldinger, R., Aldrich, H., \& Ward, R. (1990). Opportunities, group characteristics, and strategies, In R. Waldinger, H. Aldrich, \& R. Ward (Eds.), Ethnic entrepreneurs: Immigrant business in industrial societies (pp. 13-48). London, UK: Sage.

Werbner, P. (1984). Business on trust: Pakistani entrepreneurship in the Manchester garment trade. In R. Ward \& R. Jenkins (Eds.), Ethnic communities in business: Strategies for economic survival (pp. 1-19). Cambridge, MA: Cambridge University Press.

Werbner, P. (1990). Renewing an industrial past: British Pakistani entrepreneurship in Manchester. Migration, 8, 17-41.

Wilson, K. L., \& Portes, A. (1980). Immigrant enclaves: An analysis of the labor market experiences of Cubans in Miami. American Journal of Sociology, 86, 295-319. 